Rev. Saúde públ., S. Paulo, 25(1): 3-10, 1991

\title{
A Engenharia Genética
}

\author{
José Alberto Neves Candeias*
}

\begin{abstract}
CANDEIAS, J.A.N. A engenharia genética. Rev. Saúde públ., S. Paulo, 25: 3-10, 1991. São abordados os progressos havidos com as técnicas de engenharia genética, capazes de alterar o potencial genético de um organismo, quer pela introdução, quer pela supressão de novos genes estruturais. São mencionadas algumas das aplicações em geral e, em particular, possibilidades de uso no campo da medicina. É feita uma análise crítica dos benefícios e riscos envolvidos.
\end{abstract}

Descritores: Engenharia genética, métodos. DNA recombinante.

"Mythology is full of hybrid creatures such as the Sphinx, the Minotaur and the Chimera, but the real world is not".Stanley N. Cohen, 1975

\section{Introdução}

Falar de engenharia genética é caracterizar um conjunto de processos que permitem a manipulação do genoma de microrganismos vivos, com a conseqüente alteração das capacidades de cada espécie. Esta possibilidade de alteração das potencialidades genéticas dos organismos resultou da colaboração intima e constante entre a chamada ciência básica e a ciência aplicada. Não que tal colaboração tenha sido programada com vistas a tornar realidade aquela intervenção. $O$ que ocorreu foi a aquisição de novos conhecimentos fundamentais, como o esclarecimento da estrutura do ADN, e o ter sido possível decifrar o código genético, depois de serem caracterizados seus padrōes fundamentais: cada codon corresponde a um só aminoácido, ainda que diferentes codons possam especificar o mesmo aminoácido; os dois primeiros nucleotídeos são, em geral, suficientes para especificar determinado aminoácido; codons com sequiências semelhantes especificam quimicamente os mesmos aminoácidos. Foi ainda fundamental a descoberta de que o código genético é praticamente o mesmo em quase todos os organismos vivos. Existem exceçðes, mas estas, apesar de raras, acabam por salientar a elevada capacidade de adaptação do código genético a alteraçðes ambientais, o que permite a um organismo vivo "fazer a leitura" do codon conforme sua melhor conveniência, Não devemos esquecer que os

* Departamento de Microbiologia do Instituto de Ciências Biomédicas da Universidade de São Paulo - São Paulo, SP - Brasil.

Separatas/Reprints: J. A. N. Candejas - Av. Prof. Lineu Prestes, 1374 - 05508 - São Paulo, SP - Brasil. processos de mutação podem ocorrer em um gene codificador de uma proteína essencial e que se este só está presente numa única cópia, no genoma, o resultado final é letal. Por esta razão a Natureza tornou possivel "fazer a leitura" do codon com vistas ao melhor desempenho do organismo vivo.

As técnicas de engenharia genética ou, mais corretamente, a tecnologia de ADN recombinante (ADNr), começaram a ser definidas no início do ano de 1970 , com a utilização de vetores de clonagem, em geral, plasmídeos e genomas virais, lançando-se mãos das chamadas enzimas de restrição que permitiam cortar $0 \mathrm{ADN}$ em pontos bem definidos, isolando-se assim fragmentos de ácido nucléico passíveis de serem introduzidos no genoma de um organismo com moléculas idênticas de ADN. É a chamada clonagem molecular, em que, numa primeira operação, repetimos, se procede ao corte da molécula do ácido nucléico e, numa segunda fase, à inserção do fragmento do ADN no ácido nucléico de uma célula hospedeira compatível. Quando esta se divide, duplica a molécula do fragmento de $A D N$ inserido. A primeira experiência de clonagem de $A D N$ foi feita em 1972 por um grupo de pesquisadores chefiados por Paul Berg, que veio a receber o prêmio Nobel em 1980. A partir da data da experiência original, o desenvolvimento havido na tecnologia do $\mathrm{ADNr}$ tem sido surpreendente. Em 1987 surgiu uma nova contribuição, a chamada reação de polimerização em cadeia (PCR), que veio dar nova feição às experiências de clonagem molecular. Esta técnica permite amplificar determinado locus, quando se dispõe de quantidades minimas de $A D N$ genômico. Esta amplificação é feita à custa de uma polimerase extraída da bactéria Thermus

(1) Série comemorativa do $25^{\circ}$ aniversário da Revista de Saúde Pública. 
aquaticus, em cerca de 20 a 30 ciclos, com controle adequado da temperatura, podendo, ao final, obter-se milhões de cópias daquele fragmento de $A D N$. O que antes do advento da técnica PCR demorava semanas de trabalho intenso, hoje não dura mais do que algumas horas.

Os plasmídeos encontram-se em bactérias e em algumas leveduras e têm a capacidade de duplicarse autonomamente, possuindo, em geral, genes que lhes conferem resistência a antibióticos, como a ampicilina e a tetraciclina. São estes genes que permitem distinguir células hospedeiras que possuem o ADNr das células que não o possuem. Um dos plasmídeos mais freqüentemente usado é o pBR322, construído com fragmentos de ADN obtidos de diversos outros plasmídeos (pBR313pBR318-pBR320), com o objetivo de obter um produto final com genes de resistência a antibióticos (ampicilina e tetraciclina) e sítios de clivagem bem definidos.

Outros vectores de clonagem são os bacteriófagos, que, uma vez enxertados com ADNr, podem ser introduzidos na célula hospedeira por um processo de infecção. Podemos ainda usar os chamados cosmídeos que são vectores genéticos mistos, com um gene que confere resistência a antibióticos, com a origem de replicação de um plasmídeo, com a extremidade "cohesiva" de ADN do bacteriófago lambda e com sequiências de restrição às quais podem unir-se fragmentos de ácido nucléico exógeno de até $45 \mathrm{~Kb}$ de tamanho, capacidade muito superior à dos outros vectores. Além do bacteriófago lambda, podem usar-se os bacteriófagos $\mathrm{M} 13$ e $\mathrm{Mu}$ e vectores obtidos do vírus SV40. A tecnologia do ADNr recorre, por vezes, a segmentos de ADN que possuem a capacidade de se inserir, casualmente, em outros segmentos de ácido nucléico. São as sequiuencias de inserção (SI), segmentos relativamente curtos de ADN, com cerca de $1.800 \mathrm{pb}$ e os transposons ( $\mathrm{Tn})$, segmentos mais longos de 2.500 a $40.000 \mathrm{pb}$.

$\mathrm{Na}$ tecnologia do ADNr a participação das enzimas ou endonucleases de restrição é da maior importância. Cada enzima possui um padrão específico de corte da molécula de $A D N$, do que resulta uma série de fragmentos genômicos que podem ser isolados, clonados e seqüenciados. A suspeita da existência de tais enzimas data do início de 1960 e desde esta data já foram identificadas mais de 250, umas conhecidas por endonucleases do tipo I e outras, do tipo II. As primeiras são proteínas multiméricas capazes de cortar e modificar a molécula de ADN, necessitando, para tanto, da presença de ATP, Mg++ e Sadenosilmetionina (SAM). Pelo contrário as endonucleases do tipo II são proteínas monoméricas que necessitam somente de $\mathrm{Mg}++$ para serem ati- vadas e fazem o corte da molécula de ADN, tal como as do tipo I, em pontos de natureza específica, isto é, reconhecem seqüências de nucleotídeos específicas, fazendo o corte destas, ou em sítios próximos das mesmas.

Tão importantes quanto as endonucleases de restrição são as ligases, enzimas que possuem a capacidade de ligar covalentemente as extremidades livres dos fragmentos de $\mathrm{ADN}$, o que pode ocorrer tanto in vivo como in vitro. Realmente estas enzimas não fazem mais do que catalizar a formação de uma ligação fosfodiester entre o terminal hidroxilo $3^{\prime}$ e 0 terminal fosfato $5^{\prime}$ de dois nucleótidos adjacentes, restabelecendo a continuidade estrutural do ADN. A reação de ligação do $A D N$ in vitro reduz a susceptibilidade do ácido nucléico à degradação nucleolítica intracelular, preserva os terminais "cohesive" gerados pelas endonucleases de restrição e permite obterem-se moléculas de ADNr circulares ou lineares. Por estas razões a ligação in vitro é a preferida tecnicamente.

Como já referimos, a manipulação genética compreende quatro fases: escolha do fragmento de ADN a ser utilizado, corte deste fragmento, sua transferência e inserção no genoma de determinada célula e, finalmente, seleção das células que possuem as moléculas do clone desejado. Esta última fase é a que oferece maior dificuldade, por ser muito demorada, dependendo da utilização dos chamados bancos de ADN. Um banco de ADN possui todas as moléculas de ADN geradas pela inserção do ácido nucléico da fonte de interesse num determinado vector, o que significa poderem existir vários tipos de bancos, conforme a natureza da inserção e o tipo de vector utilizado. Assim o tipo de banco a ser preparado vai depender do tipo de pesquisa em curso.

Os elementos que formam os bancos genômicos são, como já referimos, clones de ADN do genoma de determinado organismo vivo, clones estes obtidos com vectores como, por exemplo, bacteriófagos, que aceitam inserçōes de grandes tamanhos. Estas inserçôes têm a vantagem de permitir a obtenção de todo o genoma em um número reduzido de clones, ou, por vezes, do gene intacto em um único clone.

Além dos bancos de ADN, recorre-se, muitas vezes, a bancos de $c A D N$, de muito menor complexidade, uma vez que contêm somente as sequiências codificadoras de determinada proteína expressa no tipo célula que está sendo usado. Neste caso a identificação do clone é de muito mais simples execução. O primeiro passo para construir um banco de cADN consiste em isolar o ARN mensageiro; em seguida este é transformado em um hibrido ADN: ARN, o que se consegue 
usando a transcriptase reserva; com o auxílio de uma outra enzima, a polimerase I, o ARN daquele híbrido é substituído por ADN, e só então esta fita dupla ADN: ADN é inserida num vector e introduzida na célula hospedeira.

A identificação do clone pode ser feita por hibridização de sondas de ADN ou ARN marcadas radioativamente, com as bases complementares do clone, sendo a localização feita por autoradiografia. Quando um fragmento de ADN clonado é transcrito e traduzido in vivo, a proteína resultante pode ser identificada imunologicamente, desde que se possua o anticorpo específico, em geral, marcado com I ${ }^{125}$. Trata-se de um outro processo de identificação.

Com a possibilidade hoje existente de utilizar sintetizadores automáticos, a síntese de oligonucleotideos e oligopeptideos tornou-se uma tarefa laboratorial altamente simplificada. $O$ ADN pode ser sintetizado sob a forma de fita simples, tanto de pequeno tamanho, quanto de tamanho maior. Usando as fitas de pequeno tamanho pode introduzir-se mutações em genes. As fitas de ADN de grande tamanho (200pb) usam-se tanto como sondas, como para construir genes sintéticos que têm a enorme vantagem de possuir sítios de clivagem para as endonucleases de restrição, que não se encontram nos genes naturais, o que torna a manipulação daqueles muito mais facilitada.

\section{Aplicaçóos Práticas em Geral}

São em grande número os objetivos práticos da pesquisa biológica, desde a satisfação da curiosidade humana sobre a natureza da vida, até ao controle e eliminação de doenças humanas, de outros animais e de plantas, enfim, a melhoria da qualidade de vida. Com as diversas técnicas de ADNr vai-se tornando mais rápido e eficiente $o$ atendimento àqueles objetivos. Mesmo desconhecendo, ainda, os limites das possibilidades da aplicação prática da engenharia genética, não resta dúvida de que passamos a dispor de tecnologia altamente promissora para a solução de problemas de natureza variada.

\section{Setor Industrial}

Nos processos de fermentação industrial está-se assistindo ao atendimento de seus objetivos com maior rapidez, lançando mão das técnicas de recombinação genética, com as quais passou a ser possível o uso de microrganismos recombinantes. Ai estão as produções, em larga escala, de insulina, de hormônio do crescimento, de interferon alfa humano com atividade biológica contra infecções ocasionadas por vírus e contra algumas formas de tumores malignos humanos, de vacinas e de reagentes biológicos usados na identificação e quantificação de proteínas específicas. A engenharia genética veio contornar algumas situações que, até então, faziam prever um futuro não muito brilhante para a obtenção de produtos industriais, por processos de fermentação de produtos vegetais, face às necessidades alimentares da população mundial. Afinal, em grande número de casos, as matérias-primas utilizadas para obtenção de produtos industriais são as mesmas a que se recorre para a produção de alimentos. Esta duplicidade de uso poderia levantar problemas de difícil solução, particularmente, em países carentes de ampla produção agrícola. Hoje, com as técnicas de engenharia genética, ampliam-se as oportunidades de aplicação por vias alternativas, que deixam de interferir com a produção de alimentos. É ainda maior o rendimento conseguido, maior o grau de pureza e maior a estabilidade dos produtos finais.

\section{Setor Alimentar}

No campo da microbiologia de alimentos, as técnicas de ADNr enfrentam ainda algumas barreiras, principalmente as resultantes da carência de estudos sobre os determinantes bioquímicos e genéticos das funções que certos microrganismos desempenham na produção de alimentos. Apesar desta situação, já se conseguiram resultados promissores, tanto na obtenção de microrganismos que intervêm na produção de alimentos, quanto na produção de aminoácidos usados como aditivos durante o processamento de alimentos. As perspectivas futuras permitem vislumbrar estratégias que tornem possível o uso de algumas funções microbianas na melhoria do rendimento daquela produção. Uma destas estratégias é a clonagem, em plantas, de genes microbianos codificadores de resistência à ação deletéria de fatores ambientais, ou genes microbianos codificadores de substâncias osmoreguladoras que facilitariam o seu crescimento em ambientes muito secos ou de elevada salinidade. Outra importante aplicação da engenharia no setor alimentar é a obtenção de microrganismos capazes de produzir compostos químicos, enzimas ou líquidos energéticos com substratos não utilizáveis diretamente pelo homem, de fácil renovação e não poluidores do ambiente.

\section{Setor Químico}

O setor químico é um outro campo em que a engenharia genética pode trazer, e já está trazendo, ponderáveis benefícios. A diminuição dos custos de produção de novos produtos de elevada deman- 
da é fator que a indústria química não pode desconsiderar, estando como está, constantemente envolvida na procura de métodos competitivos para a produção. No campo da química, em geral, e especificamente na chamada química fina, apesar das técnicas clássicas poderem atender às necessidades de produção, a engenharia genética vem ampliar e melhorar os processos de produção de matériasprimas, usando microrganismos capazes de fermentar diretamente compostos de maior complexidade, como a celulose, ou lançando mão de culturas mistas de microrganismos, capazes uns de atuar sobre os produtos de fermentação de outros, com o que se melhora o resultado final. A produção de polihidroxibutirato (PHB) pela bactéria Alcaligenes eutrophus, substância de propriedades únicas e de aplicação semelhante ao polipropileno, tem ainda sua produção em níveis de custo mais elevados que os deste último, mas estes se tornarão competitivos, na produção em larga escala, graças à engenharia genética.

\section{Produção de Antibióticos}

Genes específicos codificadores de antibióticos de bactérias e fungos podem ser clonados em algumas espécies bacterianas, o que abre boas possibilidades na manipulação genética đa produção daqueles metabolitos. Mas os resultados práticos obtidos não são, por enquanto, de grande valia, principalmente, por serem limitados os conhecimentos sobre mecanismos moleculares envolvidos na biosintese de antibióticos. Quando melhorados tais conhecimentos, a engenharia genética pode tornar possível a construção de combinações de genes capazes de codificar novos antibióticos, até hoje desconhecidos, aquilo a que poderíamos chamar de antibióticos híbridos.

\section{Produção de Vacinas}

As técnicas de $\mathrm{ADNr}$ permitem a produção de novas vacinas virais e bacterianas. No caso das virais as possibilidades para sua obtenção podem utilizar vírus inativados, vírus atenuados, proteínas virais ou peptídeos naturais ou sintéticos que apresentem um epitopo antigenicamente eficiente na produção de anticorpos. Nas vacinas bacterianas uma das possibilidades de previnir a doença ocasionada pela liberação de toxinas é usar o toxoíde. Podem usar-se vacinas bacterianas inativadas e vacinas atenuadas, mas estas apresentaram uma série de problemas, como aparecimento de reaçōes adversas, ou a própria reversão da atenuação. As possíveis aplicações das técnicas de ADNr no preparo de vacinas bacterianas compreendem a clonagem, em vetores genéticos, de antígenos bacteria- nos com boa resposta imunológica, a obtenção de bactérias toxigênicas com a fração tóxica da toxina inativa, a obtenção, em grande quantidade, de proteínas bacterianas de adesão, ou ainda a obtenção de antígenos sintéticos. Dentro destas possibilidades técnicas estão em curso pesquisas no sentido de se obterem vacinas contra $E$. coli enteropatogênica, Neisseria gonorrhoea, Treponema pallidum, Vibrio cholerae, Salmonellas e Shigella sonnei.

No caso de vacinas virais, a obtenção de proteínas com poder vacinal, utilizando as técnicas do $\mathrm{ADNr}$, tem vantagens, como a não utilização do vírus cultivável, a não administração da partícula viral completa e o custo de produção baixo. Como desvantagens devem salientar-se o poder imunizante discreto dos antígenos produzidos e a grande labilidade genética de certos vírus, de que resulta a dificuldade de preparo de vacinas eficazes. Isto é particularmente importante para os vírus de genoma constituído por ARN. Já para os vírus ADN a técnica de mutagênese dirigida permite introduzir mutaçōes suficientemente acentuadas que tornam muito baixa a frequiência de reversão da virulência. A vacina contra a febre aftosa e a vacina contra a hepatite B podem ser consideradas como modelos experimentais de produção de vacinas virais por engenharia genética.

\section{Aplicaçáo na Área Médica}

Não há quaisquer dúvidas sobre as possibilidades da engenharia genética poder manipular o genoma celular dentro de uma perspectiva, aparentemente, sem limites. No entanto, continuam presentes limitações práticas para as quais há que encontrar maneira de as controlar, se queremos estender aquela técnica ao campo da medicina humana.

Excluídas as referências já feitas a propósito da produção de antibióticos, hormônios e vacinas, algumas das outras áreas de aplicação das técnicas de ADNr no campo da medicina humana são o diagnóstico e a terapêutica genética.

\section{Diagnóstico}

Depois que passamos a conhecer a configuração genética dos organismos vivos, pelo exame do seu ADN, foi-nos colocado à disposição um importante componente das técnicas de diagnóstico, quer este se dirija à identificação de doenças de fundo genético, quer ao desenvolvimento de novos métodos de diagnóstico de doenças infecciosas, ou ao próprio diagnóstico laboratorial. 
$\mathrm{Na}$ população em geral, cada indivíduo pode apresentar diferentes versões, digamos assim, de um mesmo gene, sem que isto ocasione efeitos observáveis. Existem, no entanto, situações em que aquelas diferenças podem dar origem a profundas alterações que levam à gênese das chamadas doenças de fundo genético ou alteraçðes hereditárias, designação esta que configura a possibilidade de transmissão das mesmas de geração a geração. É já longa a lista destas doenças com o diagnóstico amparado no uso de sondas de ADN: anemias falciformes, diabetes, doença de Huntington, distrofia de Duchenne, doença de Altzheimer, fenilcetonúria, hemofilia, hipoparatiroidismo, neurofibromatose de Recklinghausen, retinite pigmentosa, retinoblastona, síndrome de Lesch-Nyhan. Mas o número de doenças de fundo genético vai muito além desta lista, conhecendo-se mais de 3.000 situaçðes clínicas dentre as quais, muito poucas dispōem de tratamento e só um reduzido número pode ser diagnosticado no período prénatal. As técnicas de ADNr usadas no diagnóstico pré-natal consistem, fundamentalmente, na purificação do ADN do paciente, obtido de células sangüíneas, líquido amniótico ou fragmento de tecido, seguida de digestão com endonucleases de restrição e separação dos fragmentos por eletroforese. Segue-se uma fase de identificação da alteração genética por hibridização, com a sonda específica para o quadro clínico suspeito. Podem ser usadas, como sondas, ARN mensageiro, ADN ou oligonucleotídeos sintéticos, conjugados com radiosótopos, enzimas ou compostos fluorescentes. Vão revelar o surgimento, ou a perda de sítios de restrição. Deste modo, a análise da herança familiar das sequiências polimórficas dos fragmentos de restrição com defeito permite, com determinada probabilidade, prever se 0 feto herdou a doença genética.

Outro aspecto de interesse na área da medicina humana, para o qual a engenharia genética trouxe notáveis progressos, é o relacionado com o diagnóstico de diversas doenças infecciosas ocasionadas por Salmonella, Campylobacter, Actinobacillus, Plasmodium, Retrovírus da síndrome de imunodeficiência adquirida (SIDA/AIDS) e vírus da hepatite B. O princípio que rege a execução técnica do diagnóstico é o mesmo do diagnóstico prénatal, apoiando-se na elevada especificidade da hibridização entre seqüências complementares de ADN.

A engenharia genética permite ainda produzir anticorpos monoclonais, mediante a clonagem em bactérias de genes capazes de fazerem sua codificação. Este tipo de anticorpos encontra importante aplicação no diagnóstico clínico, e na própria intervenção terapêutica. $O$ recurso a anticorpos monoclonais, em substituição aos anticorpos policlonais usados no diagnóstico clínico convencional, é mandatório, uma vez que sua pureza aumenta a especificidade e sensibilidade da reação, além de reduzir os custos de modo apreciável. A elevada especificidade dos anticorpos monoclonais permite execução de técnicas de diagnóstico, impraticáveis antes do seu aparecimento. É o caso da chamada técnica "tandem" que se baseia na utilização de dois anticorpos monoclonais que reconhecem, ao mesmo tempo, diferentes determinantes antigênicos de um mesmo antígeno, ou a técnica dos anticorpos monoclonais híbridos, capazes de reagir com um antígeno, por um lado, e com um antígeno diferente, por outro, ou a técnica dos anticorpos monoclonais marcados com radioisótopos que tornam possível sua localização in vivo, usando-se a resonância magnética, a tomografia ou técnicas radiológicas, em tecidos tumorais, por exemplo.

\section{Terapêutica}

O uso terapêutico dos anticorpos monoclonais abrange diversas modalidades, como a soroterapia, a terapia de certos tumores malignos, onde se processa a lise das células tumorais na presença de toxinas e complemento, ou como agentes de imunodepressão. Na soroterapia com anticorpos monoclonais que, obviamente, terão de provir de hibridomas humanos, o elevado grau de pureza dos mesmos impede o surgimento de reações indesejáveis de tipo anafilático. No tratamento de certos tumores malignos a eficiência dos anticorpos monoclonais $\varepsilon$, por enquanto, de valor discutivel, uma vez que estes se fixam tanto a antígenos de superfície de células tumorais, como de células normais, mesmo expressando aquelas alguns antígenos diferentes das células normais. As células tumorais possuem antígenos específicos próprios, mas obviamente, também expressam os antígenos das células normais. Para melhorar a seletividade têm sido usadas toxinas de ação citocida conjugadas com anticorpos monoclonais. Também, neste caso, há limitações impostas pelo fato de as próprias toxinas serem produtos estranhos ao organismo, desencadeando portanto resposta do sistema imunológico. Quando necessário, pode suprimir-se a atividade deste sistema usando anticorpos monoclonais específicos contra os linfócitos $T$, cuja participação na resposta imune é importante. $O$ uso de hibridomas pode generalizar-se para além da produção de anticorpos monoclonais, permitindo a obtenção de substâncias de maior complexidade com eventuais aplicações. Vale referir que é também possível produzir anticorpos monoclonais pela clonagem de genes codifica- 
dores de anticorpos em bactérias, usando as técnicas de engenharia genética.

A terapêtica genética, propriamente dita, também conhecida por geneterapia é uma aplicação possível das técnicas de ADNr, em doenças de fundo genético, cujas lesões são conhecidas. A intervenção pode ser feita por substituições do segmento genômico alterado, ou por introdução da informação genética normal nas células que expressam a função defeituosa. Neste último caso a introdução das seqüências clonadas pode ser feita por microinoculação no núcleo celular, ou por transferência de genes mediada pelo ADN. Até o momento, a terapêutica genética encontra-se em fase experimental muito embora já tenham sido feitas tentativas no homem, em geral, mal sucedidas, ou com sucessos ainda não definidos. Ainda não são perfeitamente conhecidas as alterações celulares que podem resultar da inoculação de genes estranhos, ou mesmo se estas ocorrem, do mesmo modo que se desconhece o grau de estabilidade dos genes introduzidos. É em relação às possibilidades da terapêutica genética que se têm levantado as maiores objeções, trazendo para o campo da discussão uma série de problemas morais e éticos, que, certamente, não devem ser desconsiderados. No dizer de Krimsky tudo resultou do fato de "as ciências biológicas terem passado da idade da inocência para idade da ansiedade".

\section{Riscos e Benefícios}

Em 1976 as pesquisas com ADNr, em desenvolvimento na Universidade de Harward e no Instituto de Tecnologia de Massachusets (MIT), foram suspensas temporariamente, pela administração da cidade de Cambridge, Estado de Massachusets (EUA). A alegação para tal intervenção baseou-se no fato de não ter havido ainda consenso, entre os cientistas, sobre os verdadeiros riscos que o processo envolvia. Esta situação, com argumentos e contra-argumentos, prolongou-se por cerca de um ano, quando voltaram a ser liberadas as pesquisas, sob determinadas condições, que obrigavam à rígida submissão às normas estabelecidas pelo "National Institut of Health" (NIH). E a questão ficou encerrada, não sem que, até hoje, novas diretrizes continuem sendo estabelecidas.

$O$ organograma da estrutura que controla as experiências com ADNr, nos EUA, estabelece, ao nivel das instituições de pesquisa, a organização de um Comité Institucional de Segurança Biológica (IBC), de que fazem parte, além dos pesquisadores, alguns membros da comunidade, ao qual estão subordinadas as atividades de pesquisa desenvolvidas na instituição, sob a res- ponsabilidade do investigador responsável. Esse Comité responde; em nivel federal, perante um Escritório de atividades com ADNr, subordinado ao diretor do NIH, perante o qual também responde 0 Comité Consultivo sobre ADNr (RAC). Toda esta organização está, naturalmente, subordinada ao Ministério da Saúde, Educação e Bem-Estar Social. As atividades do RAC são de assessoramento do Ministro e do Diretor do NIH sobre a "coordenação dos programas e atividades federais relacionadas com a investigação sobre $\mathrm{ADNr}$ ", para que sejam respeitadas as diretrizes estabelecidas nos trabalhos desenvolvidos nas instituiçøes de pesquisa, empresas públicas e privadas. Em relação a estas últimas ficou definido que suas informaçбes ao NIH não seriam remetidas, oficialmente, sem que houvesse a garantia de estarem amplamente protegidos os seus segredos profissionais.

Cabe ainda ao RAC definir a política a seguir sobre o registro de patentes de novas técnicas de ADNr, sobre atividades internacionais neste campo e sobre problemas que possam surgir com trabalhos em larga escala.

Vez por outra voltam, no entanto, alguns críticos a manifestar-se, alegando que os riscos não compensam alguns benefícios obtidos, e que ao final, encarada a situação do ponto de vista prático, tanto técnico quanto financeiro, nunca 0 "impossível" poderá tornar-se "possível". E apresentam argumentos de múltipla natureza. Por exemplo, o que aconteceria com Streptococcus Bhemolíticos que viessem a receber um plasmídeo possuidor de um gene codificador da resistência à penicilina, resistência não encontrada nas diversas cepas daquela bactéria? Então, quadros clínicos com a escarlatina e patologias reumatismais e renais, hoje, prontamente controladas por aquele antibiótico, passariam a ampliar o contingente das doenças antibiótico-resistente. A este respeito vale lembrar que a Natureza, talvez até com a ajuda do próprio homem, parece ter tomado a iniciativa, criando a oportunidade de aparecimento de uma mutação, que teria tomado um sub-grupo dos estreptococos resistentes à penicilina. Membros deste sub-grupo poderiam ser os responsáveis pela síndrome do choque tóxico, quadro de aparecimento bem recente e que já está preocupando os centros de controle das doenças infecciosas. Outro exemplo refere-se à possibilidade de cepas de $E$. coli, que fazem parte da flora intestinal humana, poderem adquirir a capacidade de sintetizar toxina botulínica, ou determinado hormônio, situações que resultariam em óbvios resultados desastrosos. Mais um exemplo, é o caso da implantação, em cepas de $E$. coli, de um gene de um vírus que ocasiona tumores malignos em animais de laboratório, de que poderia resultar o desenvolvimento 
de tumores no homem, cujo intestino é habitat natural daquela bactéria. Todos estes exemplos, ou pelo menos alguns deles, parecem não levar em consideração que é necessário o atendimento a um certo número de situaçð̃es, para que uma bactéria não patogênica venha a transformar-se em patogênica: capacidade de multiplicação e sobrevivência no hospedeiro, transmissão de animal a animal, e resistência aos mecanismos de defesas do hospedeiro. A criação de novos organismos na Natureza é um demorado processo, tantas e tantas vezes mal sucedido e onde a evolução está sempre ditando suas regras. Idêntica situação no laboratório parece ainda mais problemática.

Mesmo com a aceitação do que poderiam considerar-se as desvantagens de alto risco, não é muito difícil vislumbrar as possibilidades práticas benéficas da técnica do ADNr. E os exemplos também se acumulam num amplo horizonte de benesses de múltipla natureza. Passamos a dispor de insulina a baixo custo, graças à possibilidades de cepas de $E$. coli sintetizarem aquele hormônio. Culturas desta mesma bactéria são capazes de produzir enormes quantidades de hormônio do crescimento, por custos que não podem comparar-se aos que assistiam à sua produção pelo processo clássico, no qual, para conseguir cerca de 5 miligramas do produto era necessário sacrificar algumas dezenas de milhares de carneiros para retirar os cérebros, dos quais se extraía aquele hormônio.

A técnica do ADNr é também de enorme utilidade na área da biologia molecular e bioquímica, como no estudo de propriedades enzimáticas de determinada proteína passivel de ser obtida em grandes quantidades com a implantação do gene codificador da mesma no fago lambda. Os estudos de regulação da síntese de um ARN mensageiro, ou, ainda, as pesquisas in vitro da mutagenese dirigida, são outros campos onde a engenharia genética tem excelente uso.

Confrontando-se os benefícios com os riscos que as técnicas do $\mathrm{ADNr}$ podem acarretar para a humanidade, não há como não aceitar que a controvérsia continuará envolvendo cientistas, educadores, políticos e o público em geral, sejam quais forem os argumentos apresentados. Do mesmo modo, continuarão as pesquisas no campo da engenharia genética, com benefícios reais para a humanidade e com riscos téoricos, que sempre podem, é claro, adquirir foros de realidade. Mas isto é próprio da natureza humana. Que os assuntos sobre que possa cair nossa reflexão a respeito desta controvérsia sejam ou não relevantes é questão sempre sujeita a discussão: uns preferirão argumentos a favor, a outros agradarão mais argumentos contrários. Simplesmente a escolha não pode, nem deve ser feita por plebiscito, além de confi- gurar a insólita situação de imaginarmos ser possivel interferências estranhas regularem a atividade dos cientistas. Foram os próprios cientistas interessados nas atividades de pesquisa com $\mathrm{ADNr}$ que, pela prineira vez, chamaram a atenção para os possíveis riscos inerentes. Mas até agora, ao contrário do que muitas vezes acontece na sociedade em geral, têm sabido comportar-se com a necessária responsabilidade. E por ser assim e, provavelmente, continuar sendo é que é aceitável a orientação de se desenvolverem novas pesquisas, ao mesmo tempo que deve dar-se continuidade a uma isenta análise que estabeleça sua validade. Naturalmente o processo não irá desenvolver-se sem contrariedades. Pelo contrário, será árduo e assinalado por alternativas de coerção perante influências adversas, mas também deverá ter vitórias fecundas. E a ciência moderna sabe muito bem o que lhe é permitido e o que lhe é vedado. A dialética que usa é de método crítico de suas experiências, o que lhe confere autoridade para saber que o seu domínio da Natureza é já suficientemente utilizável na melhoria da condição humana.

CANDEIAS, J. A. N. [Genetic engineering]. Rev. Saúde públ., S. Paulo, 25: 3-10, 1991. This paper deals with the progress made in genetic engineering techniques, capable of altering the genetic potential of an organism, either by the introduction or the suppression of new structural genes. Some of the general applications are described as are also, more particularly, their uses in the field of medicine. A critical analysis of the benefits and risks involved is also undertaken.

Keywords: Genetic engineering, methods. DNA recombinant.

\section{Bibliografia}

ALTER, B.P. Prenatal diagnosis of hemoglobinopathies and other hematologic diseases. J. Pediat., 95:501-13, 1979.

ANDERSON, W.F. \& FLETCHER, J.C. Gene therapy in human beings: when is it ethical to begin. New Engl.J. Med, 303:1293-6, 1980.

BALBAS, P. et al. Plasmid Vector pBR322 and its Special Purpose Derivatives: a review. Gene, 50:3-40, 1986.

BEVERLY, P.L. Antibodies and cancer therapy. Nature. 297:328-61, 1982.

BIRNBOIN, H.C. \& DOLLY, J.A rapid alkaline extraction procedure for screening recombinant plasmid DNA. Nucl. Acids Res., 7:1513-25, 1979.

BITTLE, J.L. et al. Protection against foot-and-month disease by immunization with a chemically synthesized peptide predict from the viral nucleotide sequence. $\mathrm{Na}$ ture, 298:30-3, 1982.

BITTNER, M. et al. Electrophoretic transfer of protein and nucleic acids from slab gels into diazobenziloxymethil paper on nitrocellulose sheets. Anal. Biochem., 102:459-71, 1980. 
BRENNER, S. et al. Plasmids: hybrids: hybrids between ColE1 plasmids and $E$. coli bacteriophage A. Gene, 17:27-44, 1982

CASKEY, C.T. Disease diagnosis by recombinant DNA methods, Science, 236:1223-9, 1987.

CHARNAY, P. et al. Biosynthesis of hepatitis B surface antigen in $E$. coli. Nature, 286:893-5, 1980.

CLARK, A.J.L. et al. Biosynthetic human insulin in the treatment of diabetis. Lancet, 2:354-7, 1982.

CLEWELL, D.B. Plasmid drug resistance and gene transfer in the genus Streptococcus. Microbiol. Rev., 45:409-36, 1981 .

COHEN, S.N. et al. Construction of biologically functional plasmids in vitro. Proc. Nat. Acad. Sci. USA, 70:3240-4, 1973.

DEMAIN, A.L. Industrial microbiology. Science, 214:987-95, 1981.

DORKINS, H.R. \& DAVIES, K.E. Recombinant DNA technology in the clinical sciences. Trends Biotechnol., 3:195-200, 1985.

ENQUIST, W.L. et al. Cloning of herpes simplex type 1 DNA fragments in a bacteriophage lambda vector. Science. 203:541-4, 1979.

GOEDDEL, D.V. et al. Direct expression in E. coli of a DNA sequence coding for human growth homone. Nature, 281:544, 1979.

GRUNSTEIN, M. \& HOGNESS, D. Colony hybridization: a method for the isolation of cloned DNAs that contain a specific gene. Proc. Nat. Acad. Sci. USA, 72:3961$4,1975$.

HAAS, M.J. Methods and applications of genetic engineering. Food Technol., 38:68-77, 1984.

HOPWOOD, D.A. \& MERRICK, M.J. Genetics of antibiotic production. Bacteriol. Rev., 41:595-635, 1977.

ITAKURA, K. et al. Synthesis and use of synthetic oligonucleotides. Ann. Rev. Biochem., 53:323-56, 1984.

KARN, J. et al. Novel bacteriophage cloning vector. Proc. Nat. Acad. Sci. USA, 77:5172-6, 1980.

KIPPER, H. et al. Cloning of a DNA of major antigenic footand-month disease virus and expression in $E$. coli. Nature, 289:555-9, 1981.

KLECKNER, N.J. et al. Genetic engineering in vivo using translocable drug-resistance elements. J. Mol. Biol., 116:125-59, 1977.

KNORR, D. \& SNISKEY, A.J. Biotechnology in food production and processing. Science, 229:1224-8, 1985.
KRIMSKY, S. Genetic alchemy: the social history of the recombinant DNA controversy. Cambridge, Mass., M.I.T. Press, 1982.

LOMOVSKAYA, N.D. et al. Genetics and molecular biology of Streptomyces bacteriophages. Microbiol. Rev., 44:206-29, 1980.

MAXAM, A.M. \& GILBERT, W. A new method for sequencing DNA. Proc. Nat. Acad. Sci. USA, 74:560-8, 1978.

MICKLOS, D.A. \& BLOON, M.V. DNA restriction analysis. Carolina Tips, 52:21-3, 1989.

NIRENBERG, M.V. \& MATTARI, J.H. The dependance of cell-free protein synthesis in $E$. coli cepon naturally occurring or synthetic polyribonucleotides. Proc. Nat. Acad. Sci. USA, 47:1588-602, 1961.

OGDEN, R. \& ADAMS, D.A. Recombinant DNA technology. Carolina Tips, 52:13-9, 1989.

OLIVER, D. Protein secretion in E. coll. Ann. Rev. Microbiol., 39:615-48, 1985.

PRIMROSE, S.B. The application of genetically engineered microorganisms in the production of drugs. J. appl. Bacteriol., 61:99-106, 1986.

REISFELD, R.R. Monoclonal antibodies to human malignant melanoma. Nature, 298:325-9, 1982.

SANCAR, A. et al. Simple method for identification of plasmid coded proteins. J. Bact., 137:692-3, 1979.

SHANABRUCH, W.G. et al. Spontaneous mutators generated by the insertion of transposable elements. J. Bact., 147:827-35, 1981

SILHAVY, T.J. et al. Mechanism of protein localization. Microbiol. Rev., 47:313-44, 1983.

SMITH, M. In vitro mutagenesis. Ann. Rev. Genet., 19:423-62, 1985.

SOUTHERN, E.N. Detection of specific sequences among DNA fragments separated by gel electroforesis. $J$. Mol. Biol., 98:503-17, 1975.

TIOLLAIS, P. et al. Biology of hepatitis B virus. Science, 213:406-11, 1981

WATSON, J.D. \& CRICK, F.H.C. A structure for deoxyribose nucleic acid. Nature, 171:737-8, 1953.

WHITE, R.L. DNA in medicine. Lancet, 1:1257-62, 1984.

WOODRUF, H.B. Natural products from microorganisms. Science, 208:1225-9, 1980.

Recebido para publicação em 2/4/1991 